\title{
AKTIVITAS FISIK, ASUPAN ENERGI DAN STATUS GIZI WANITA PEMETIK TEH DI PTPN VIII BANDUNG, J AWA BARAT
}

\author{
(Physical Acitivity, Energy Intake, and Nutritional Status of Women Workers of Tea Plantation \\ in PTPN VIII Bandung, West J ava) \\ Venny Agustiani Mahardikawati ${ }^{1}$ dan Katrin Roosita ${ }^{2 *}$ \\ ${ }_{1}^{1}$ Program Studi Gizi Masyarakat dan Sumberdaya Keluarga, Fakultas Pertanian (FAPERTA) IPB. \\ 2 Departemen Gizi Masyarakat, Fakultas Ekologi Manusia (FEMA), IPB \\ Tel: 0251-8628304/8621258; Fax: 0251-8625846/8622276
}

\begin{abstract}
Quality of human resources is very important to improve productivity. The worker productivity is correlated with nutritional status and health status. The objective of the research is to analyze physical activity, energy intake, nutritional status, of women workers at Tea Plantation PTPN VIII Bandung, West J ava. The cross sectional design was used in this study to elaborate physical activity, nutritional status, and productivity of tea picker's women. The criteria of study sample were tea picker's women at cluster area of Malabar tea plantation of PTPN VIII Bandung, having infant and they were willing to be interviewed. The total number of 92 women sample was chosen randomly. Primary data consisted of physical activity recall ( $2 \times 24$ hours), food consumption recall ( $2 \times 24$ hours), anthropometry data (weight and height), and productivity (passage of tea sprout). Secondary data were included data of PT Perkebunan Nusantara VIII Bandung, West J ava. The result showed that more than a half of samples having active or moderate physical activity level (PAL). The physical activity level of samples during work day (average $P A L=1.87)$ was higher than holiday (average $P A L=1.69)(p<0.05)$. The physical activity was related to energy expenditure. According to Schofield equation, energy expenditure of sample during workday (average $=2362 \mathrm{kcal}$ ) was significantly higher $(p \varangle 0.05)$ than day off (average $=2134 \mathrm{kcal}$ ). This result is related to Oxford equation, energy expenditure of sample during workday (average $=2223 \mathrm{kcal}$ ) was significantly higher than holiday (average $=2011 \mathrm{kcal}$ ). The related factors of energy expenditure are body weight and age. Energy intake on workday and day off were respectively $2362 \mathrm{kcal}$ and $2134 \mathrm{kcal}$. The average energy adequacy level during workday and day off according to Schofield and Oxford equation were not significantly different, respectively $97,2 \%$ and $103,3 \%$ The majority of samples had normal nutritional status, and $30.4 \%$ of the sample was overweight. The energy adequacy level according to Schofield and Oxford equation are related to nutritional status of women workers.
\end{abstract}

Keywords: physical activity, energy expenditure, nutritional status, plantation women worker

\section{PENDAHULUAN}

Aktivitas fisik atau disebut juga aktivitas eksternal ialah suatu rangkaian gerak tubuh yang menggunakan tenaga atau energi. Jenis aktivitas fisik yang sehari-hari dilakukan antara lain berjalan, berlari, berolahraga, mengangkat dan memindahkan benda, mengayuh sepeda, dan lain-lain. Setiap kegiatan fisik menentukan energi yang berbeda menurut lamanya

* Penulis untuk korespondensi, Departemen Gizi Masyarakat, FEMA, IPB; Tel: 0251-8628304/8621258: Fax: $0251-8625846 / 8622276$

Email: kroosita@yahoo.com intensitas dan sifat kerja otot (Williamson, 1993 dalam FKM UI, 2007).

Aktivitas fisik menentukan kondisi kesehatan seseorang. Kelebihan energi karena rendahnya aktivitas fisik dapat meningkatkan risiko kegemukan dan obesitas. Oleh karena itu, angka kebutuhan energi individu disesuaikan dengan aktivitas fisik (FAO/WHO/UNU, 2001). Aktivitas fisik dan angka metabolisme basal $(A M B)$ atau basal metabolic rate (BMR) merupakan komponen utama yang menentukan kebutuhan energi. AMB dipengaruhi oleh umur, jenis kelamin, berat badan, dan tinggi badan (Almatsier, 2004). 
Pengeluaran energi yang tidak sebanding dengan aktivitas fisik dapat menyebabkan terjadinya penumpukan lemak yang pada akhirnya dapat meningkatkan risiko kegemukan dan obesitas. Menurut WHO (1995) IMT lebih dari 30 termasuk obesitas dan IMT lebih dari 25 menyebabkan obesitas. IMT dapat memantau status gizi orang dewasa khususnya yang berkaitan dengan kekurangan dan kelebihan berat badan normal yang memungkinkan seseorang dapat mencapai usia harapan hidup lebih panjang.

Tujuan dari penelitian ini ialah untuk menganalisis aktivitas fisik, pengeluaran energi, konsumsi energi dan status gizi pada wanita pemetik teh di PTPN VIII Bandung, Jawa Barat.

\section{METODE PENELITIAN}

\section{Desain, Tempat, dan Waktu Penelitian}

Penelitian ini menggunakan desain cross sectional study, semua data yang dibutuhkan dikumpulkan dalam satu waktu (Singarimbun \& Effendi, 2006). Penelitian dilakukan di kawasan perkebunan teh milik PTPN VIII di Kecamatan Pangalengan, Bandung Selatan, pada cluster terpilih yaitu kebun Malabar. Pemilihan lokasi berdasarkan pertimbangan kemudahan akses, jarak, dan topografi serta kehomogenan antar cluster. Penelitian dilakukan sejak Maret hingga Juni 2008.

\section{Prosedur Penarikan Contoh}

Populasi contoh ialah wanita pemetik teh yang memiliki anak usia dini (0-72 bulan) dan dapat diwawancarai dengan jumlah sebanyak 504 keluarga yang dipilih secara acak saat penelitian sebelumnya (Sunarti, Roosita, \& Herawati, 2007). Contoh tersebar ke dalam lima cluster yang ada di kawasan perkebunan yaitu Purbasari $(n=96)$, Malabar $(n=102)$, Talun Santosa $(n=67)$, Sedep $(n=96)$, dan Rancabali ( $\mathrm{n}=146)$. Jumlah contoh pada cluster terpilih, yaitu perkebunan Malabar berjumlah 102 keluarga, namun pada saat pengumpulan data lima keluarga telah pindah dan lima orang lainnya sudah tidak bekerja di perkebunan Malabar sehingga contoh penelitian berjumlah 92 .

\section{Pengolahan dan Analisis Data}

Data yang digunakan ialah data primer dan data sekunder. Data primer meliputi kondisi sosial demografi contoh, aktivitas fisik, konsumsi pangan, dan antropometri (berat badan dan tinggi badan). Pengumpulan data pri- mer dilakukan dengan teknik wawancara langsung dengan menggunakan kuesioner. Data aktivitas fisik digunakan untuk menghitung kebutuhan energi. Aktivitas fisik dihitung berdasarkan recall aktivitas $2 \times 24$ jam. Data konsumsi pangan digunakan untuk menghitung konsumsi energi yang selanjutnya dibandingkan dengan kebutuhan energi untuk menentukan tingkat konsumsi energi. Data antropometri digunakan untuk menghitung indeks masa tubuh (IMT) sebagai indikator status gizi.

Wawancara contoh dilakukan secara acak sehingga terambil hasil recall baik hari kerja maupun hari libur. Total contoh yang direcall pada hari kerja pertama atau kedua sebanyak 85 orang, sedangkan total contoh yang direcall pada hari libur pertama atau kedua sebanyak 25 orang. Total contoh yang direcall pada saat gabungan hari kerja dan hari libur sebanyak 92 orang. Dua orang contoh pada saat hari libur kedua mengalami sakit, sehingga konsumsi energi dan pengeluaran energinya sangat rendah. Oleh karena itu, dua contoh tersebut tidak dimasukkan dalam perhitungan rata-rata konsumsi dan kebutuhan energi. Selanjutnya total contoh yang direcall pada saat hari kerja dan hari libur (hari gabungan) menjadi 90 orang.

Analisis dilakukan dengan menggunakan statistik deskriptif dan inferensia. Uji hubungan antar variabel dan uji beda menggunakan statistik inferensia. Statistik inferensia yang digunakan ialah korelasi Pearson dan uji T. Uji normalitas data dilakukan dengan uji Kolmogorov-Smiornov. Analisis data diolah dengan menggunakan Microsoft Excel 2003 dan Statistical Program for Social Sciences (SPSS) version 12.0 for windows.

\section{HASIL DAN PEMBAHASAN}

\section{Kondisi Sosial Demografi Contoh}

Usia contoh pada penelitian ini berkisar antara 21 sampai 55 tahun yang tergolong usia produktif. Lebih dari separuh jumlah contoh berpendidikan sekolah dasar dan $14.1 \%$ di antaranya tidak tamat SD sehingga tergolong rendah. Lebih dari separuh contoh memiliki status sebagai karyawan harian lepas. Hampir seluruh contoh memiliki upah masih di bawah UMR dan upah rata-rata yang diterima contoh per bulan sebesar Rp. 327,546.7. Lebih dari separuh jumlah contoh memiliki jumlah anggota keluarga lima sampai tujuh orang dengan jumlah anggota rata-rata sebanyak 5 orang. Lebih dari separuh jumlah contoh tergolong miskin dan 
$37 \%$ contoh termasuk tidak miskin dengan pendapatan per kapita rata-rata Rp. 162,542.5 per bulan.

Lebih dari separuh jumlah contoh memiliki masa kerja antara 1-14 tahun dengan masa kerja contoh rata-rata 13.8 tahun. Sebagian besar contoh bekerja antara 6 sampai 8 jam per hari dengan rata-rata 5.9 jam per hari. Selengkapnya data sosial demografi contoh disajikan pada Tabel 1.

Tabel 1. Sebaran Contoh menurut Kondisi Sosial Demografi

\begin{tabular}{|c|c|c|}
\hline \multirow{2}{*}{ Variabel } & \multicolumn{2}{|c|}{ J umlah } \\
\hline & $\mathbf{n}$ & $\%$ \\
\hline \multicolumn{3}{|l|}{ Usia (WNPG 2004) } \\
\hline Dewasa muda (21-29 tahun) & 19 & 20.6 \\
\hline Dewasa madya (30-49 tahun) & 71 & 77.2 \\
\hline Dewasa akhir (50-55 tahun) & 2 & 2.2 \\
\hline Jumlah & 92 & 100 \\
\hline \multicolumn{3}{|l|}{ Jenjang pendidikan } \\
\hline Tidak sekolah & 2 & 2.2 \\
\hline Tidak tamat SD & 13 & 14.1 \\
\hline SD/sederajat & 68 & 73.9 \\
\hline SMP/sederajat & 7 & 7.6 \\
\hline SMA/sederajat & 2 & 2.2 \\
\hline Jumlah & 92 & 100 \\
\hline \multicolumn{3}{|c|}{ Pendapatan perkapita (Kabupaten Bandung, BPS 2006) } \\
\hline \multicolumn{3}{|c|}{ Miskin } \\
\hline \multicolumn{3}{|l|}{ Tidak miskin } \\
\hline Rata-rata \pm sd & \multicolumn{2}{|c|}{$162,542.5 \pm 75,980.2$} \\
\hline \multicolumn{3}{|l|}{ Besar keluarga } \\
\hline 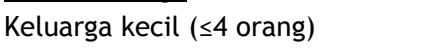 & 40 & 43.5 \\
\hline Keluarga sedang (5-7 orang) & 49 & 53.3 \\
\hline Keluarga besar ( $\geq 8$ orang) & 3 & 3.2 \\
\hline Jumlah & 92 & 100 \\
\hline Rata-rata \pm sd & \multicolumn{2}{|c|}{$4.7 \pm 1.2$} \\
\hline \multicolumn{3}{|l|}{ Status karyawan } \\
\hline$\overline{\text { Karyawan harian lepas }}$ & 63 & 68.5 \\
\hline Karyawan tetap & 29 & 31.5 \\
\hline Jumlah & 92 & 100 \\
\hline \multicolumn{3}{|l|}{ Lama bekerja } \\
\hline 1-14 tahun & 52 & 56.5 \\
\hline 15-29 tahun & 32 & 34.8 \\
\hline 30-43 tahun & 8 & 8.7 \\
\hline Jumlah & 92 & 100 \\
\hline Rata-rata \pm sd & \multicolumn{2}{|c|}{$13.8 \pm 10.6$} \\
\hline \multicolumn{3}{|l|}{ Jam kerja per hari } \\
\hline$<6$ jam perhari & 18 & 19.6 \\
\hline 6-8 jam perhari & 74 & 80.4 \\
\hline Jumlah & 92 & 100 \\
\hline Rata-rata \pm sd & \multicolumn{2}{|c|}{$5.9 \pm 0.6$} \\
\hline \multicolumn{3}{|c|}{ Upah per bulan (UMR Kab. Bandung 2008) } \\
\hline Di bawah UMR (<Rp. 672,000.00) & 87 & 94.6 \\
\hline Di atas UMR ( $\geq$ Rp. $672,000.00)$ & 5 & 5.4 \\
\hline Jumlah & 92 & 100 \\
\hline Rata-rata \pm sd & \multicolumn{2}{|c|}{$327,546.7 \pm 163,169.9$} \\
\hline
\end{tabular}

\section{Aktivitas Fisik}

Menurut FAO/WHO/UNU (2001) pengkategorian tingkat aktivitas fisik dengan nilai physical activity level (PAL) dibagi menjadi 3, yaitu ringan $(1.40 \leq \mathrm{PAL} \leq 1.69)$, sedang $(1.70$ $\leq \mathrm{PAL} \leq 1.99)$, dan berat $(2.00 \leq \mathrm{PAL} \leq 2.40)$. Angka kebutuhan energi dihitung dengan pendekatan pengeluaran energi, yaitu angka metabolisme basal dikali dengan tingkat aktivitas fisik.

Tabel 2 menunjukkan sebaran contoh menurut tingkat aktivitas fisik. Tingkat aktivitas fisik contoh pada hari kerja lebih tinggi dibandingkan dengan hari libur dan gabungan hari kerja dan libur dengan nilai PAL rata-rata $1.87(p<0.05)$. Tingkat aktivitas fisik contoh pada hari libur dan gabungan hari kerja dan libur masing-masing sebesar 1.69 dan 1.84. Hampir seluruh contoh $(90.6 \%)$ pada hari kerja memiliki tingkat aktivitas fisik yang tergolong sedang, sedangkan lebih dari separuh jumlah contoh (52\%) memiliki tingkat aktivitas fisik ringan pada hari libur. Sebanyak 5.9\% contoh memiliki tingkat aktivitas fisik yang berat pada hari kerja dengan nilai PAL lebih dari 2.00. Perbedaan tersebut dipengaruhi dari pekerjaan memetik teh dengan alokasi waktu antara 6 sampai 8 jam per hari memiliki tingkat aktivitas fisik yang lebih tinggi dibandingkan dengan aktivitas kegiatan rumah tangga pada hari libur.

Tabel 2. Sebaran Contoh menurut Tingkat Aktivitas Fisik (Physical Activity Level/ PAL)

\begin{tabular}{lcccccc}
\hline $\begin{array}{c}\text { Tingkat aktivitas } \\
\text { fisik (PAL) }\end{array}$ & $\begin{array}{c}\text { Hari } \\
\text { Kerja } \\
(\mathbf{n = 8 5 )}\end{array}$ & $\begin{array}{c}\text { Hari } \\
\text { Libur } \\
(\mathbf{n = 2 5 )}\end{array}$ & $\begin{array}{c}\text { Hari Kerja } \\
\text { dan Libur } \\
\mathbf{( n = 9 0 )}\end{array}$ \\
\cline { 2 - 7 } & $\mathbf{n}$ & $\%$ & $\mathbf{n}$ & $\%$ & $\mathbf{n}$ & $\%$ \\
\hline Ringan (1.40-1.69) & 3 & 3.5 & 13 & 52 & 10 & 11.1 \\
Sedang (1.70-1.99) & 77 & 90.6 & 12 & 48 & 78 & 86.7 \\
Berat (2.00-2.40) & 5 & 5.9 & 0 & 0 & 2 & 2.2 \\
Jumlah & 85 & 100 & 25 & 100 & 90 & 100 \\
\hline \multicolumn{1}{c}{ Rata-rata \pm sd } & \multicolumn{3}{c}{$1.87 \pm 0.08$} & $1.69 \pm 0.13$ & $1.84 \pm 0.11$ \\
\hline
\end{tabular}

Pengeluaran energi digunakan untuk menentukan angka kebutuhan energi (estimated average requirement/EAR). Untuk menentukan angka kebutuhan energi akan lebih tepat jika menggunakan EAR dibandingkan dengan AKG, karena EAR menggunakan angka metabolisme basal berdasarkan kelompok umur, jenis kelamin, dan ukuran tubuh (berat) dan aktifitas fisik (FAO/WHO/UNU, 2001; WNPG, 2004).

Terdapat perbedaan persamaan angka metabolisme basal antara Schofield equation 
yang digunakan FAO/WHO/UNU 2001 dengan Oxford equation yang digunakan WNPG 2004. Asumsi WNPG 2004 menggunakan Oxford equation karena dianggap lebih sesuai, sampel yang digunakan termasuk populasi Asia (China dan Filipina). Adapun sampel Schofield equation ialah populasi Eropa Barat dan Amerika Utara. Walaupun demikian, WHO berasumsi angka metabolisme basal Schofield equation dapat mewakili populasi secara universal dan representatif.

Pengeluaran energi contoh rata-rata menurut persamaan angka metabolisme basal Schofield equation pada hari kerja, hari libur, serta gabungan hari kerja dan libur berturutturut sebesar 2362 kkal, 2134 kkal dan 2324 kkal. Pengeluaran energi pada hari kerja lebih tinggi dibandingkan pada hari libur $(p<0.05)$. $\mathrm{Hal}$ tersebut juga berlaku pada pengeluaran energi dengan menggunakan Oxford equation, pengeluaran energi contoh menurut persamaan angka metabolisme basal Oxford equation pada hari kerja, hari libur, serta hari kerja dan hari libur berturut-turut sebesar 2223 kkal, 2011 kkal, dan 2188 kkal. Pengeluaran energi pada hari kerja lebih tinggi dibandingkan pada hari libur $(\mathrm{p}<0.05)$.

Tabel 3 menunjukkan jenis aktivitas, alokasi waktu serta pengeluaran energi contoh per jenis kegiatan. Jenis kegiatan contoh dikelompokkan menjadi empat kelompok kegiatan besar, yaitu aktivitas umum (general personal activities), kegiatan transportasi (means of transport), kegiatan rumah tangga (domestic chores), dan kegiatan pertanian (agricultural activities) sebagai pekerjaan utama.

Kegiatan umum yang dilakukan contoh meliputi tidur, berpakaian, mandi, istirahat/ duduk, makan, menonton TV, dan beribadah. Alokasi waktu dan pengeluaran energi terbesar pada kelompok aktivitas umum yaitu tidur dan dan menonton TV baik pada hari kerja dan hari libur. Pada hari libur, alokasi waktu untuk kegiatan umum seperti tidur dan menonton TV lebih lama dibandingkan dengan dengan hari kerja. Alokasi waktu untuk tidur pada hari kerja dan hari libur masing-masing sebesar 7 jam dan 9 jam, dengan pengeluaran energi antara 300 sampai 450 kkal per hari.

Alokasi waktu dan pengeluaran energi terbesar pada kelompok kegiatan transportasi pada hari kerja yaitu terdapat pada jenis kegiatan berangkat kerja (berjalan kaki), dan pada hari libur yaitu ke rumah tetangga (jalanjalan). Alokasi waktu pada hari kerja dan hari libur berturut-turut yaitu 0.9 dan 0.6 jam per hari dengan pengeluaran energi antara 150 sampai 170 kkal per hari.

Kegiatan rumah tangga yang dilakukan yaitu memasak, mencuci piring, mencuci pakaian, menyetrika, menyapu dan membersihkan rumah, merawat anak, mengambil air, mengambil kayu, dan kegiatan rumah tangga lainnya. Alokasi waktu untuk memasak pada hari kerja dan hari libur berturut-turut sebesar 1.7 jam dan 3 jam per hari, sedangkan alokasi waktu untuk merawat anak pada hari kerja dan hari libur sebesar 0.9 dan 3.2 jam per hari. Pengeluaran energi untuk seluruh kegiatan rumah tangga berkisar antara 500 sampai 1000 kkal per hari.

Kegiatan pertanian sebagai pekerjaan utama contoh meliputi memetik teh dan pengarahan dari mandor. Pada hari kerja, contoh memetik teh rata-rata 5.8 jam per hari dengan pengeluaran energi sebesar 834.7 kkal untuk pengeluaran energi bedasarkan AMB Oxford equation dan 867.1 kkal untuk pengeluaran energi bedasarkan AMB Schofield equation.

Setiap kegiatan memiliki faktor aktivitas yang berbeda yang disebut dengan PAR (physical activity ratio). Semakin tinggi nilai PAR, menunjukkan semakin berat kegiatan atau aktivitas tersebut dilakukan.

\section{Tingkat Konsumsi Energi}

Konsumsi energi contoh rata-rata pada hari kerja, hari libur, dan gabungan hari kerja dan libur berturut-turut sebesar 2244 kkal, 2176 kkal, dan 2245 kkal. Tingkat konsumsi energi dibedakan berdasarkan cara penghitungan kebutuhan energi yaitu menurut cara Schofield equation dan Oxford equation, dengan nilai rataan dari gabungan hari kerja dan hari libur masing-masing sebesar 97.2 dan 103.3\%. Tingkat konsumsi pada hari kerja, hari libur dan gabungan hari kerja dan hari libur terlihat bahwa perhitungan dengan menggunakan Oxford equation relatif lebih tinggi dibandingkan Schofield equation (Tabel 4).

Hasil uji statistik menunjukkan tidak terdapat perbedaan konsumsi dan tingkat konsumsi energi di antara ketiga kelompok hari, dan berdasarkan cara perhitungan yang berbeda yaitu berdasarkan Oxford maupun Schofield equation. Hal tersebut diduga dari pola konsumsi energi antara 3 kelompok hari tersebut mempunyai pola yang relatif sama, meskipun kebutuhan energi pada hari kerja lebih tinggi $(p<0.05)$ dibandingkan hari libur baik berdasarkan oxford maupun Schofield equation. 
Tabel 3. Jenis Aktivitas, Alokasi Waktu dan Pengeluaran Energi Contoh

\begin{tabular}{|c|c|c|c|c|c|c|c|c|}
\hline \multirow{3}{*}{$\begin{array}{l}\text { Jenis } \\
\text { aktivitas }\end{array}$} & \multirow{3}{*}{ Padanan aktivitas* } & \multirow{3}{*}{ PAR** } & \multicolumn{2}{|c|}{$\begin{array}{l}\text { Alokasi waktu } \\
\text { (jam/hari) }\end{array}$} & \multicolumn{4}{|c|}{ Pengeluaran energi } \\
\hline & & & \multirow{2}{*}{$\begin{array}{l}\text { Hari } \\
\text { kerja }\end{array}$} & \multirow{2}{*}{$\begin{array}{l}\text { Hari } \\
\text { libur }\end{array}$} & \multicolumn{2}{|c|}{$\begin{array}{l}\text { Oxford } \\
\text { equation }\end{array}$} & \multicolumn{2}{|c|}{$\begin{array}{l}\text { Schofield } \\
\text { equation }\end{array}$} \\
\hline & & & & & $\begin{array}{l}\text { Hari } \\
\text { kerja }\end{array}$ & $\begin{array}{l}\text { Hari } \\
\text { libur }\end{array}$ & $\begin{array}{c}\text { Hari } \\
\text { kerja }\end{array}$ & $\begin{array}{l}\text { Hari } \\
\text { libur }\end{array}$ \\
\hline \multicolumn{9}{|c|}{ Aktivitas umum/ General personal activities } \\
\hline Tidur & Sleeping & 1 & 7.0 & 9.0 & 306.0 & 448.0 & 382 & 457.6 \\
\hline Berpakaian & Dressing & 2.3 & 0.3 & 0 & 4.4 & 3.5 & 4.7 & 3.7 \\
\hline Mandi & Washing hands/ face and hair & 2.3 & 0.4 & 0.5 & 55.6 & 54.4 & 60.6 & 58.5 \\
\hline Istrahat, duduk & Light leisure activities & 1.4 & 2.0 & 1.6 & 150.5 & 115.4 & 160 & 129.1 \\
\hline Makan & Eating & 1.4 & 0.5 & 0.3 & 19.3 & 24.0 & 20.8 & 25.5 \\
\hline Nonton TV & Watching TV & 1.4 & 1.4 & 2.8 & 131.4 & 181.1 & 143.2 & 199.4 \\
\hline Beribadah & Light leisure activities & 1.4 & 1.0 & 0.6 & 47.6 & 49.9 & 55.3 & 51.5 \\
\hline Sub total & & & 12.6 & 14.6 & 714.5 & 876.3 & 827 & 925.3 \\
\hline \multicolumn{9}{|c|}{ Kegiatan transportasi/ Means of transport } \\
\hline Berjalan kaki, berangkat kerja & Walking downhill & 3.2 & 0.9 & 0 & 149.0 & 0 & 147.8 & 0 \\
\hline $\begin{array}{l}\text { Jalan-jalan, ke rumah } \\
\text { tetangga }\end{array}$ & Walking around & 2.5 & 0.2 & 0.6 & 21.2 & 153.5 & 21.8 & 163.0 \\
\hline Berangkat kerja, naik motor & Sitting on a motor cycle & 1.5 & 0.1 & 0 & 7.1 & 0 & 9.2 & 0 \\
\hline Sub total & & & 1.2 & 0.6 & 177.3 & 153.5 & 178.8 & 163 \\
\hline \multicolumn{9}{|c|}{ Kegiatan rumah tangga/ Domestic chores } \\
\hline Memasak & Cooking & 2.1 & 1.7 & 3.0 & 179.5 & 345.0 & 184.5 & 364.0 \\
\hline Mencuci piring & Washing dishes & 1.7 & 0.1 & 0.5 & 6.4 & 50 & 6.8 & 60 \\
\hline Mencuci pakaian & Washing clothes & 2.8 & 0.7 & 1.0 & 94.2 & 80 & 98.3 & 83.0 \\
\hline Menyetrika & Ironing clothes & 1.7 & 0.1 & 0 & 10.5 & 50 & 11.1 & 60 \\
\hline $\begin{array}{l}\text { Menyapu dan membersihkan } \\
\text { rumah }\end{array}$ & Sweeping and house cleaning & 2.3 & 0.3 & 0.4 & 46.0 & 52.1 & 42.5 & 57.0 \\
\hline Merawat anak & Child care & 2.5 & 0.9 & 3.2 & 130 & 303.9 & 135.0 & 318.7 \\
\hline Mengambil air & Collecting water & 4.5 & 0.1 & 0 & 7.0 & 12.8 & 8.0 & 13.0 \\
\hline Mengambil kayu & Chopping wood (for fuel) & 4.2 & 0.3 & 0.5 & 8.7 & 87.3 & 9.1 & 90 \\
\hline Kegiatan rumah tangga lainnya & Housework & 2.8 & 0 & 0 & 3.3 & 0 & 3.6 & 0 \\
\hline Sub total & & & 4.2 & 8.6 & 485.6 & 981.1 & 497.7 & 1045.7 \\
\hline \multicolumn{9}{|c|}{ Kegiatan pertanian/ Agricultural activities } \\
\hline Memetik teh & Collecting cocoa & 2.9 & 5.8 & 0 & 834.7 & 0 & 849.7 & 0 \\
\hline Pengarahan dari mandor & Standing & 1.5 & 0.1 & 0 & 10.5 & 0 & 11.6 & 0 \\
\hline Sub total & & & 6 & 0 & 845.2 & 0 & 861.3 & 0 \\
\hline Total & & & 24.0 & 24.0 & 2223.0 & 2011.0 & 2362.0 & 2134.0 \\
\hline
\end{tabular}

Keterangan : ${ }^{*}$ Padanan aktivitas yang terdapat dalam FAO/WHO/UNU (2001)

${ }^{* *}$ Physical activity ratio (PAR/ Faktor aktivitas)

Tabel 4. Konsumsi Rata-rata, Kebutuhan dan Tingkat Konsumsi Energi Contoh pada Hari Kerja, Hari Libur, dan Gabungan Hari kerja dan Libur (Hari Kerja dan Hari Libur)

\begin{tabular}{lccc}
\hline \multicolumn{1}{c}{ Variabel } & \multicolumn{3}{c}{ Rata-rata \pm sd } \\
\cline { 2 - 4 } & Hari kerja $(\mathbf{n = 8 5})$ & Hari libur $(\mathbf{n = 2 5 )}$ & $\begin{array}{c}\text { Gabungan hari kerja dan libur } \\
\text { (Hari kerja dan libur }(\mathbf{n = 9 0}) \text { ) }\end{array}$ \\
\hline Kebutuhan (kkal/hari) & $2362 \pm 235$ & $2134 \pm 158$ & $2324 \pm 158$ \\
Schofield equation & $2223 \pm 141$ & $2011 \pm 149$ & $2188 \pm 155$ \\
Oxford equation & $2244 \pm 355$ & $2176 \pm 477$ & $2245 \pm 328$ \\
Konsumsi (kkal/hari) & & & \\
Tingkat konsumsi (\%) & $95.1 \pm 15.4$ & $103.2 \pm 16.1$ & $97.2 \pm 13.5$ \\
Schofield equation & $101.1 \pm 14.7$ & $116.7 \pm 29.1$ & $103.3 \pm 14.1$ \\
Oxford equation & & &
\end{tabular}

Keterangan :
${ }^{*}$ Berdasarkan pendekatan pengeluaran energi menurut angka metabolisme basal (AMB) Schofield equation dalam WHO (2001)

${ }^{* *}$ Berdasarkan pendekatan pengeluaran energi menurut angka metabolisme basal (AMB) Oxford equation dalam WNPG (2004) 
Kerja berat merupakan kegiatan yang memerlukan upaya fisik yang kuat selama periode kerja. Pada waktu bekerja, pengeluaran energi meningkat. Makin besar gerakan otot makin tinggi pula pengeluaran energi kerjanya (Sastrowinoto, 1985).

\section{Status Gizi}

Rata-rata berat badan contoh sebesar $52.0 \pm 5.9 \mathrm{~kg}$ dan tinggi badan contoh rata-rata sebesar $148.6 \pm 5.0 \mathrm{~cm}$. Berat contoh berada di atas rata-rata berat badan wanita dewasa penduduk Indonesia, yaitu $47.8 \mathrm{~kg}$ sampai $49.5 \mathrm{~kg}$, namun tinggi badan contoh rata-rata lebih pendek dari rata-rata tinggi badan wanita dewasa penduduk Indonesia yaitu $149.9 \mathrm{~cm}$ sampai 150.7 cm (Jahari \& Jus'at, 2004).

Tabel 5 menunjukkan lebih dari separuh jumlah contoh (67.4\%) berada pada kategori normal dan sebanyak $30.4 \%$ mengalami kegemukan (IMT>25) serta 2.2\% contoh mengalami gizi kurang $(I M T<18.5)$. Persentase overweight atau kegemukan pada contoh yang melebihi $5 \%$ menjadi masalah kesehatan masyarakat. Menurut Azwar (2004) batasan masalah kesehatan masyarakat terjadi jika overweight lebih dari 5\% dari populasi. Menurut Atmarita dan Fallah (2004), masalah gizi pada usia produktif tidak saja karena kurus (IMT<18.5), tetapi juga kegemukan $(I M T>25)$. Dua masalah gizi (double burden) ini juga tidak hanya terjadi pada usia produktif di ibu kota, tetapi di wilayah kumuh perkotaan maupun pedesaan juga sudah terjadi dan ada kecenderungan meningkat terutama untuk masalah kegemukan.

Tabel 5. Sebaran Contoh menurut Indeks Massa Tubuh (IMT)

\begin{tabular}{ccc}
\hline Status Gizi & $\mathbf{n}$ & $\%$ \\
\hline Kurus $(\mathrm{IMT}<18.5)$ & 2 & 2.2 \\
Normal $(18.5 \leq \mathrm{IMT} \leq 24.9)$ & 62 & 67.4 \\
Overweight $(25 \leq \mathrm{IMT} \leq 29.9)$ & 28 & 30.4 \\
Jumlah & 92 & 100 \\
Rata-rata \pm sd & $23.6 \pm 2.6$ \\
\hline
\end{tabular}

Faktor-faktor yang Berhubungan dengan Aktivitas Fisik dan Pengeluaran Energi

Hasil uji statistik menunjukkan semakin tinggi pengeluaran energi maka semakin tinggi tingkat aktivitas fisik (PAL). Pengeluaran energi menurut persamaan AMB Oxford equation dan Schofield equation berkorelasi dengan besarnya tingkat aktivitas fisik $(r=0.678, p<0.01$ dan $r=0.722, p<0.01)$. Menurut Suhardjo dan Kusharto (1992) seseorang yang memiliki aktivitas fisik yang berat akan mengalami proses oksidasi dalam sel yang lebih aktif dibandingkan dengan orang yang melakukan aktivitas fisik yang ringan. Keadaan ini mengakibatkan meningkatnya pengeluaran energi per hari.

Faktor-faktor yang berhubungan dengan pengeluaran energi baik menurut persamaan AMB Oxford equation dan Schofield equation ialah berat badan $(r=0.552, \quad p<0.01$ dan $r=0.488, p<0.01)$ dan usia $(0.213, p<0.05$ dan $0.328, p<0.01)$. Semakin bertambah berat badan, maka energi yang dikeluarkan akan semakin besar. Demikian pula dengan faktor usia, semakin bertambah usia sampai usia tertentu maka pengeluaran energi akan semakin besar. Menurut FAO/WHO/UNU (2001) komposisi dan ukuran tubuh dapat mempengaruhi angka metabolisme basal sehingga pada akhirnya dapat meningkatkan pengeluaran energi.

\section{Faktor-faktor yang Berhubungan dengan Status Gizi}

Angka metabolisme basal dihitung menggunakan persamaan Schofield equation dan Oxford equation. Dari hasil perhitungan tersebut diperoleh dua angka kebutuhan energi rata-rata contoh yaitu $2324 \mathrm{kkal}$ dan $2188 \mathrm{kkal}$ dengan tingkat konsumsi rata-rata berdasarkan kedua angka kebutuhan energi masing-masing 97.2\% dan $103.3 \%$ untuk angka kebutuhan menurut FAO/WHO/UNU (2001) dan WNPG (2004). Terdapat hubungan yang sangat signifikan $(r=0.307, p<0.01$ dan $r=0.283, p<0.01)$ antara status gizi dengan tingkat konsumsi energi menurut data FAO/WHO/UNU (2001) dan WNPG (2004). Hal tersebut mengindikasikan bahwa semakin tinggi tingkat konsumsi energi maka IMT contoh akan semakin tinggi. Hal ini menunjukkan bahwa kelebihan energi dapat menyebabkan risiko terjadinya kegemukan.

\section{KESIMPULAN}

Tingkat aktivitas contoh tertinggi pada hari kerja dengan nilai PAL rata-rata sebesar 1.87. Demikian pula dengan pengeluaran energi, pengeluaran energi contoh menurut persamaan angka metabolisme basal Shofield equation dan Oxford equation lebih tinggi pada hari kerja. Faktor yang berhubungan dengan tingkat aktivitas fisik contoh ialah pengeluaran energi, sedangkan faktor-faktor yang berhubungan dengan aktivitas fisik contoh ialah usia dan berat badan. Lebih dari separuh jumlah contoh berada pada kategori status gizi normal dan sebanyak $30.4 \%$ mengalami kegemukan (IMT>25). Tingkat konsumsi energi contoh ratarata berkisar 95 sampai 115\%. Faktor-faktor 
yang berhubungan dengan status gizi contoh ialah tingkat konsumsi energi berdasarkan kebutuhan energi menurut Schofield equation dan Oxford equation.

\section{UCAPAN TERIMA KASIH}

Terima kasih disampaikan kepada Dr. Euis Sunarti selaku ketua tim peneliti proyek riset yang didanai oleh neys van hoogstraten Foundation (NHF) atas bantuan informasi dan dana publikasi. Bapak Ir. Nandi Suhandi beserta staf PTPN VIII Unit Perkebunan Malabar yang telah memberikan izin tempat untuk melakukan penelitian serta kerja sama yang baik, keluarga Bapak Suhendar atas keramahan yang diberikan, Pemerintahan serta warga Desa Banjarsari Kecamatan Pangalengan atas bantuan yang diberikan, serta teman-teman peneliti atas kerja sama yang baik selama pengambilan data di Pengalengan, dan seluruh pihak yang telah membantu dan mendukung pelaksanaan penelitian ini.

\section{DAFTAR PUSTAKA}

Almatsier S. 2002. Prinsip Dasar Ilmu Gizi. Gramedia Pustaka Utama, Jakarta.

Atmarita \& Fallah TS. 2004. Analisis Situasi Gizi dan Kesehatan Masyarakat. Dalam Soekirman, Kusumaseta, Pribadi, Ariani, Jus'at, Hardinsyah, Dahrulsyah, Firdausy (Eds), Ketahanan Pangan dan Gizi di Era Otonomi Daerah dan Globalisasi. Prosiding Widyakarya Nasional Pangan dan Gizi, 17-19 Mei. LIPI, Jakarta.
Azwar A. 2004. Aspek Kesehatan dan Gizi dalam Ketahanan Pangan. Dalam Hardinsyah, Dahrulsyah, Firdausy (Eds), Ketahanan Pangan dan Gizi di Era Otonomi Daerah dan Globalisasi. Prosiding Widyakarya Nasional Pangan dan Gizi, 17-19 Mei. LIPI, Jakarta.

FAO/WHO/UNU. 2001. Human Energy Requirement. FAO/WHO/UNU, Rome

[FKM UI]. Fakultas Kesehatan Masyarakat Universitas Indonesia. 2007. Gizi dan Kesehatan Masyarakat. Raja Grafindo Persada, Jakarta.

Jahari AB \& Jus'at I. 2004. Review Data Berat Badan dan Tinggi Badan Penduduk Indonesia. Dalam Soekirman, Kusumaseta, Pribadi, Ariani, Jus'at, Hardinsyah, Dahrulsyah, Firdausy (Eds), Ketahanan Pangan dan Gizi di Era Otonomi Daerah dan Globalisasi. Prosiding Widyakarya Nasional Pangan dan Gizi, 17-19 Mei. LIPI, Jakarta.

Sastrowinoto S. 1985. Meningkatkan Produktivitas Karyawan dengan Ergonomi. Pustaka Binaman Pressindo, Jakarta.

[WHO]. World Health Organization. 1995. Physical Status: The Use and Interpretation of Anthropometri. World Health Organization, Geneva.

WNPG. 2004. Ketahanan Pangan dan Gizi di Era Otonomi Daerah dan Globalisasi. LIPI, Jakarta. 